Bangl. J. Vet. Med. (2008). 6 (1): 93-97

\title{
PLASMA PHARMACOKINETICS OF CIPROFLOXACIN IN SHEEP
}

\author{
M. S. Islam, M. M. H. Sikder, M. A. Awal, M. Mostofa and A. A. Trisha \\ Department of Pharmacology, Faculty of Veterinary Science, Bangladesh Agricultural University, \\ Mymensingh-2202, Bangladesh
}

\begin{abstract}
The study was carried out to determine the biodisposition kinetics of ciprofloxacin in sheep model in Department of Pharmacology, Bangladesh Agricultural University. Healthy sheep of both sexes $(n=65)$ were divided into 13 groups, each consists of five and given a single dose of ciprofloxacin @ $5 \mathrm{mg} / \mathrm{kg}$ bwt intramuscularly .Blood sample was collected from each group of sheep at $0,0.5,1,1.5,2,2.5,3,3.5,4,6,8,10$ and 12 hours interval respectively. Serum concentration of ciprofloxacin was determined by spectrophotometric method. The pharmacokinetic parameters were measured by single compartment open model and first order kinetics. The peak concentration of ciprofloxacin was $3.56 \pm 0.15 \mu \mathrm{g} / \mathrm{ml}$, absorption half-life and biological half-life were $0.0846 \pm 1.79$ and $1.75 \pm 0.15 \mathrm{~h}$ respectively. The apparent volume of distribution was found $35.54 \mathrm{mg} /$ liter. The absorption rate constant was $8.188 \mathrm{~h}^{-1}$, MRT was $2.647 \mathrm{~h}^{-1}$ and total body clearances were found $16.88 \mathrm{~h}^{-1}$. These result suggested that a dose of $5 \mathrm{mg} / \mathrm{kg}$ bwt provides maximum plasma concentration and is effective in the control of many infectious diseases of sheep.
\end{abstract}

Key wards: Plasma pharmacokinetics, ciprofloxacin, sheep

\section{INTRODUCTION}

Ciproflocxacin a broad spectrum antibacterial has been shown to be effective in the treatment of a wide variety of infections in man and animals (Moellering, 1996; Hooper, 1998). Ciprofloxacin belongs to a class of antibacterials known as fluroquinolones. It is a synthetic antibacterial that works on bacterial DNA topoisomerase II and IV (Drlica and Zaho, 1997) and is rapidly absorbed from the site of absorption and well distributed into tissues. The fluoroquinolones are currently enjoying extensive clinical application world wide in human because of their good bioavailability and pharmacokinetic profile. Investigations into all aspects of the pharmacokinetic of all clinically relevant quinolones have been carried out notably in Europe, USA and Japan. Metabolic as well as drug-drug and drug-food interactions have also been extensively investigated (Bergan et al., 1987). A great variation in pharmacokinetic parameter in man and animals has been observed by Mattie et al. (1987).

Several numbers of investigation and research have already been completed on the pharmacokinetics parameter of Ciprofloxacin in different species (Munoz et al., 1996 and Mengozzi et al., 1996) in abroad. However; the pharmacokinetic parameters may vary across breed and variety (Ahangar et al., 2000). But pharmacokinetic data of Ciprofloxacin in native sheep are scare. Therefore, this study was undertaken to determine the pharmacokinetic parameter of Ciprofloxacin in native sheep along with dose, plasma concentration, half-life, maximum concentration in plasma, time to peak concentration, volume of distribution and therapeutic concentration. 
MATERIALS AND METHODS

Pharmacokinetics of ciprofloxacin was studied in 65 healthy sheep in the experimental pharmacological laboratory, Department of Pharmacology, Bangladesh Agricultural University.

\section{Experimental sheep}

The experiment was performed in 65 clinically healthy native sheep. The animal was under the Department of Pharmacology, Bangladesh Agricultural University. The animals was provided with normal feed and water to get acclimatized for 8 weeks before the study to make sure that none of them had received any medication for this period. All sheep were kept in good housing. They were divided into 13 groups (A-M) with five sheep in each group.

\section{Administration of ciprofloxacin and sampling}

Ciprofloxacin (Cipryl $^{\mathbb{R}} 50 \mathrm{ml}, 1 \mathrm{ml}$ contain $50 \mathrm{mg}$ ciprofloxacin) was administered intramuscularly at the rate of $5 \mathrm{mg} / \mathrm{kg}$ body weight with the help of syringe and needle. $5 \mathrm{ml}$ of blood samples were collected from jugular vein of each sheep at $0.5,1.0,1.5,2.0,2.5,3.0,3.5,4.0,6.0,8.0,12.0$ hour interval strictly under aseptic conditions.

\section{Preparation of blood sample}

Collected blood sample was transferred into hematocrit tube and it was allowed to stand for 20 minutes and then centrifuged at $4000 \mathrm{rpm}$ for 15 minutes, serum was separated and stored at $-20^{\circ} \mathrm{C}$ till further analysis.

\section{Analytical procedure}

Ciprofloxacin concentration was measured by UV-spectrophotometeric revised method by De et al. (1993). The method involves deproteinization of plasma samples by using isopropyl alcohol and measuring the absorbance at $280 \mathrm{~nm}$. Since isopropyl alcohol gave high absorbance of its own in the blank samples therefore the method was modified and improved. Before running the plasma samples standard curve for Ciprofloxacin was made.

\section{Statistical analysis}

The data was analyzed statistically by ' $t$ ' test described by Khan (1989).

\section{Kinetic parameters}

The plasma concentration versus time was analysed by single compartment open model. Kinetic parameters like maximum concentration of ciprofloxacin $\left(\mathrm{C}_{\max }\right)$, time to peak concentration $\left(\mathrm{T}_{\max } \mathrm{h}\right)$, half life of absorption $\left(t^{1} / 2(\alpha) \text {, distribution half life }\left(t^{1} / 2\right) \text {, elimination half life } t_{(\beta)}\right)^{1 / 2 h}$, area under curve (AUC), volume of distribution $\mathrm{V}_{\mathrm{d}}\left(\mathrm{mg} /\right.$ litre), absorption rate constant $(\mathrm{Ka})$, distribution rate constant $(\mathrm{K})$, elimination rate constant $\mathrm{K}_{\mathrm{e}}\left(\mathrm{h}^{-1}\right)$, mean residual time MRT $(h)$, therapeutic concentration of the drug $\left\{{ }^{t} c_{p}(t h e r)\right\}$ body clarence $(C L)$ were determined.

\section{RESULTS AND DISCUSSION}

\section{Plasma pharmacokinetics of ciprofloxacin}

After administration of a single dose of ciprofloxacin, concentration in the plasma started to rise from 0.5 hour and peaked after 1.61 hours. Then the concentration began to decline with an elimination rate constant of 0.67 hours. The plasma concentration of ciprofloxacin at different time intervals was plotted taking plasma concentration at $\mathrm{Y}$-axis and time interval at $\mathrm{X}$-axis (Fig. 1). 


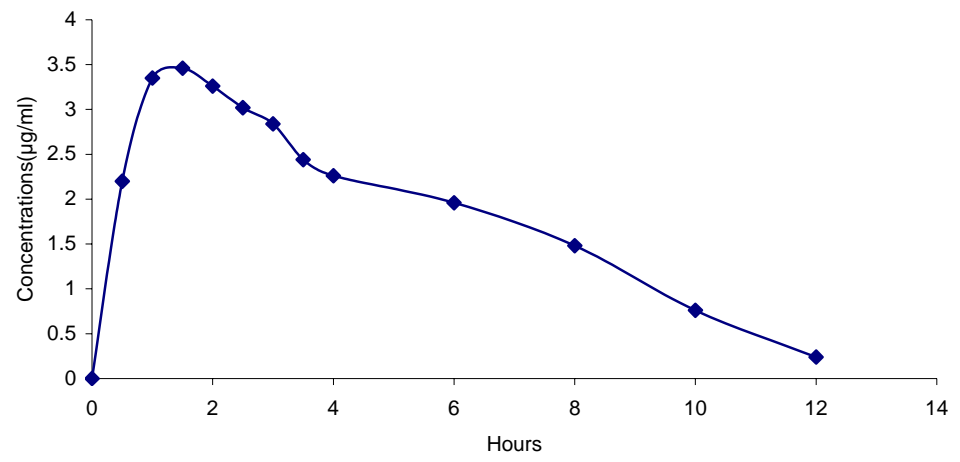

Fig. 1. Mean serum concentrations of ciprofloxacin versus time following a single intramuscular administration of $5 \mathrm{mg} / \mathrm{kg}$ body weight in sheep.

\section{Pharmacokinetics parameters}

A number of pharmacokinetic parameters were obtained after the single intramuscular dose of ciprofloxacin (Table 1).

Table 1. Pharmacokinetic parameters of ciprofloxacin in native sheep after a single intramuscular dose determined by single compartment open model

\begin{tabular}{|llll|}
\hline $\mathrm{S} / \mathrm{N}$ & Kinetic parameters & Symbols & Results \\
\hline 1 & Maximum drug concentration & $\mathrm{C}_{\max }(\mu \mathrm{g} / \mathrm{ml})$ & $3.56 \pm 0.15$ \\
2 & Time to peak concentration & $\mathrm{T}_{\max }(\mathrm{h})$ & 1.61 \\
3 & Absorption half-life & $\mathrm{t}_{1 / 2(\alpha)}(\mathrm{h})$ & 0.0846 \\
4 & Distribution half-life & $\mathrm{t}_{1 / 2}(\mathrm{~h})$ & $1.75 \pm 0.15$ \\
5 & Elimination half-life & $\mathrm{t}_{1 / 2(\beta)}(\mathrm{h})$ & 1.029 \\
6 & Area under curve & $(\mathrm{AUC}) \mu \mathrm{g} / \mathrm{ml} / \mathrm{h}$ & $2.28 \pm 1.14$ \\
7 & Volume of distribution & $\mathrm{Vd}) \mathrm{mg} / \mathrm{litre}$ & 35.54 \\
8 & Absorption rate constant & $\mathrm{Ka}(\mathrm{h})$ & $8.188 \pm 1.79$ \\
9 & Distribution rate constant & $\mathrm{K}(\mathrm{h})$ & $0.3960 \pm 0.15$ \\
10 & Elimination rate constant & $\mathrm{Ke}(\mathrm{h})$ & 0.6734 \\
11 & Mean residual time & $\mathrm{MRT}(\mathrm{h})$ & 2.647 \\
12 & Therapeutic concentration & $\mathrm{t} \mathrm{c}_{\mathrm{p}}(\mathrm{ther})$ & 7.425 \\
13 & Body clearance & $\mathrm{CL}(\mathrm{h})$ & $14.07 \pm 0.15$ \\
\hline
\end{tabular}

Ciprofloxacin was routinely prescribed to treat a variety of infections (Moellering, 1996; Hooper, 1998). No literature is available yet in its bioavailability and pharmacokinetics profile in Bangladeshi animal population. To achieve optimum therapeutic benefits of the drug, all factors which influences its pharmacokinetics and effectiveness, need to be determined. However; the pharmacokinetic parameters may vary across breed and variety (Ahangar et al., 2000). 
The pharmacokinetics analysis was performed after one compartment model. Following intramuscular administration of Ciprofloxacin in sheep, the peak serum concentration of drug occurred after approximately one and half hour $(1.61 \mathrm{hr})$. The maximum plasma concentration of Ciprofloxacin was found $3.56 \mu \mathrm{g} / \mathrm{ml}$, which is more or less similar to the literature values of $3.56 \mu \mathrm{g} / \mathrm{ml}$ and $3.57 \mu \mathrm{g} / \mathrm{ml}$ as reported by Girard et al. (1992) and Khurram et al.(2003), respectively but it was higher than some other literature value reported by Chkwuani et al. (1998) $(2.92 \mu \mathrm{g} / \mathrm{ml})$ and Kung et al. (1993) $(0.02 \mu \mathrm{g} / \mathrm{ml})$ and Abadia et al. (1995) (3.08 mg/l) and Banna et al. (1998) $(1.92 \mathrm{mg} / \mathrm{l})$ and Munoz et al. (1996) $(0.69 \pm 0.27 \mathrm{mg} / \mathrm{l})$. Maximum plasma concentration of ciprofloxacin $(3.56 \mu \mathrm{g} / \mathrm{ml})$ was the lower than the literature value of Idown and Peggins (2004) $(6.14 \mu \mathrm{g} / \mathrm{ml})$. According to Bayer et al. (1987), the peak serum concentration was 0.25 to $4.32 \mu \mathrm{g} / \mathrm{ml}$.

Biological elimination half-life was found $1.029 \mathrm{~h}^{-1}$, which is very less those values reported by Chkwuani et al. (1998), who examined $7.52 \mathrm{~h}$. The value was more or less similar to literature values reported by Khurram et al. (2003) $\left(1.45 \mathrm{~h}^{-1}\right)$ and Rao et al. (2002) $\left(1.39 \mathrm{~h}^{-1}\right)$ and Munoz et al. (1996) (1.12 $\left.\mathrm{h}^{-1}\right)$. Elimination half-life is lower than the literature values of Banna et al. (1998) $\left(2.78 \mathrm{~h}^{-1}\right)$ and Abadia et al. (1994) $\left(2.09-3.00 \mathrm{~h}^{-1}\right)$ and Nouws et al (1988) $\left(2.5 \mathrm{~h}^{-1}\right)$ and Girard et al. (1992) $\left(7.8 \mathrm{~h}^{-1}\right)$. In this study, area under curve (AUC) was found $2.28 \pm 1.46 \mu \mathrm{g} / \mathrm{ml} / \mathrm{h}$ that was lower than literature value of Khurran et al. (2003) $(18.02 \mu \mathrm{g} / \mathrm{ml} / \mathrm{h})$ and Ovando et al. (2000) $(10.32 \pm 5.137 \mu \mathrm{g} / \mathrm{ml} / \mathrm{h})$ and more or less similar to literature value reported by Rao et al. (2002) $(2.55 \mu \mathrm{g} / \mathrm{ml} / \mathrm{h})$. Calculated volume of distribution was found $35.54 \mathrm{mg} / \mathrm{l}$, was higher than the literature value reported by Khurram et al. (2003) $(28.59 \mathrm{mg} / \mathrm{l})$. This may be reason of high plasma drug concentration. It was reported by Banna et al. (1998) $(2.14 \pm 0.072 \mathrm{l} / \mathrm{kg})$ and Rao et al. (2002) (1.52 1/kg) and Ovando et al. (2000) $(3.373 \pm 0.893 \mathrm{l} / \mathrm{kg})$.

Therapeutic concentration of ciprofloxacin was 10 hour in serum and 24 hours in milk (Banna et al., 1998). In this study, therapeutic concentration of ciprofloxacin in plasma was 7.425 hour. Absorption rate constant and absorption half-life was obtained $0.0846 \mathrm{~h}^{-1}$ and $8.188 \pm 1.79 \mathrm{~h}^{-1}$ respectively. It was $1.07 \mathrm{~h}^{-1}$ in case of oral administration which reported by Khurram et al. (2003). No data absorption half-life and absorption rate constant were found in case of sheep dog, and other animals. Furthermore, distribution rate constant was obtained $0.396 \pm 0.15 \mathrm{~h}^{-1}$ it was less than the literature value $0.50 \mathrm{~h}^{-1}$, reported by Khurram et al. (2003). A significant deviation in pharmacokinetic parameters was observed from the literature values with respect to peak plasma concentration, area under curve and volume of distribution. All these factors play important role in the biodisposition of ciprofloxacin. This variation might be due to species difference, breed, variety and environment.

In conclusion, ciprofloxacin @ 5mg/kg body weight intramuscularly gives some variable pharmacokinetics parameters with regard to cited literature in native sheep and further investigation should carry out to find out the cause of variations.

\section{REFERENCES}

1. Abadia AR, Aramayona JJ, Munoz MJ, Pla Delfina JM and Bregante MA (1995). Ciprofloxacin pharmacokinetics in dogs following oral administration. Zentralbl Veterinarmed A 42 (8): 505-511.

2. Abadia AR, Aramayona JJ, Munoz MJ, Pla Delfina JM, Saez MP and Bregante MA (1994). Disposition of ciprofloxacin following intravenous administration in dogs. Journal of Veterinary Pharmacology and Therapeutics 17 (5): $384-388$.

3. Ahangar AH and Srivastava AK (2000). Pharmacokinetics of enrofloxacin in febrile crossbred bovine calves. Indian Journal of Pharmacology 32: 305-308.

4. Banna HA and Abo el-Sooud K (1998). Disposition kinetics of ciprofloxacin in lactating goats. Dtsch Tierarztl Wochenschr 105 (1): 35-38.

5. Bayer A, Gajewska A, Stephens M, Stark JM, Pathy J (1987). Pharmacokinetics of ciprofloxacin in the elderly. Respiration 51 (4): 292-295.

6. Bergan T, Thorsteinsson SB, Solberg R, Bjornskau L, Kolstad IM, Johnsen S (1987). Pharmacokinetics of ciprofloxacin: intravenous and increasing oral doses. American Journal of Medicine 82 (4A): 97-102.

7. Chkwuani CM, Cijer HAB, Oduola AMJ, Ifndn ND and Sowunmi A (1998). Single dose pharmacokinetics study of ciprofloxacin and fleroxacin in healthy male volunteers. Chemotherapy 44: 369-376.

8. De UK, Sinha KP and Banerjee NC (1993). Biokinetics of ciprofloxacin in non-febrile goats. Indian Journal of Animal Sciences 65: 269-272.

9. Drlica K and Zhao X (1997). DNA gyrase, topoisomerase IV and the 4-qoinolones. Microbiology and Molecular Biology Review 61: 377-392. 
10. Girard D, Gootz TD and McGuirk PR (1992). Pharmacokinetic studies of CP-74,667, a new quinolone, in laboratory animals. Antimicrobial Agents and Chemotherapy 36 (8): 1671-1676.

11. Hooper DC (1998). Clinical application of quinolones. Antimicrobial Agents and Chemotherapy 41: 1190-1192.

12. Idowu OR and Peggins JO (2004). Simple, rapid determination of enrofloxacin and ciprofloxacin in bovine milk and plasma by high-performance liquid chromatography with fluorescence detection. Journal of Pharmaceutical and Biomedical Analysis 35 (1): 143-153.

13. Khan AQ (1989). Epidemiology and disease control. $1^{\text {st }}$ edn., World University Service Press. Dhaka University, Nilkhet, Dhaka. pp.20-35.

14. Khurram S, Muhammad S, Munir AS, Zahid M and Zubair H (2003). Biodisposition kinetics of ciprofloxacin in male human volunteers following oral administration. Journal of Biological Sciences 3 (1): 43-47.

15. Kung K, Riond JK and Wanner M (1993). Pharmacokinetics of enrofloxacin and its metabolite ciprofloxacin after intravenous and oral administration of enrofloxacin in dogs. Journal of Veterinary Pharmacology and Therapeutics 16: 462-468.

16. Lettier JT, Rogge MC, Kaiser L, Echols RM and Heller AH (1992). Pharmacokinetics profiles or ciprofloxacin after single intravenous and oral doses. Antimicrobial Agents and Chemotherapy 36: 993-996.

17. Mattie H, Hoogeterp JJ and Terporten P (1987). The activity of ciprofloxacin against Pseudomonas aeroginosa in normal and graunlocytopenic mice. Pharmaceutisch Weekblad Scientific Edition 9: 526-529.

18. Mengozzi G, Intorre L, Bertini S and Soldani G (1996). Pharmacokinetics of enrofloxacin and its metabolite ciprofloxacin after intravenous and intramuscular administrations in sheep. American Journal of Veterinary Research 57 (7): 1040-1043.

19. Moellering RC (1996). The place of quinolones in every clinical practice. Chemotherapy 24: 54-61.

20. Munoz MJ, Lioveria P, Santos MP, Abadia AR, Aramayona JJ and Bregante MA (1996). Pharmacokinetics of ciprofloxacin in sheep after single intravenous or intramuscular administration. Veterinary Quarterly 18 (2): 45-48.

21. Nouws JF, Mevius DJ, Vree TB, Baars AM and Laurensen J (1988). Pharmacokinetics, renal clearance and metabolism of ciprofloxacin following intravenous and oral administration to calves and pigs. Veterinary Quarterly 10 (3): 156-163.

22. Ovando H, Gorla N, Poloni G, Trotti N, Prieto G and Errecalde C (2000). Intravenous pharmacokinetics of ciprofloxacin in goats. International Journal of Antimicrobial Agents 15 (1): 77-79.

23. Rao GS, Ramesh S, Ahmad AH, Tripathi HC, Sharma LD and Malik JK (2002). Pharmacokinetics of enrofloxacin and its metabolite ciprofloxacin in goats given enrofloxacin alone and in combination with probenecid. Veterinary Journal 163 (1): 85-93. 